\title{
THE IMPACT OF THE COVID-19 PANDEMIC ON MENTAL CONDITION AND THE NEED FOR PSYCHOLOGICAL SUPPORT OF STUDENTS IN JAKARTA
}

\author{
Susanto* \\ Institut PTIQ Jakarta, Indonesia \\ E-mail: susanto@ptiq.ac.id
}

\begin{abstract}
(c) (1) (2)
C 2021 by the authors. Submitted for possible open access publication under the terms and conditions of the Creative Commons Attribution (CC-BY-SA) license (https://creativecommons.org/licenses/by-sa/4.0/) doi $D O I: \underline{\text { http://dx.doi.org/10.30983/educative.v6i1.4467 }}$ *Corresponding author

Submission : April 05, $2021 \quad$ Revised: Mey 06, 2021 Published : June 30, 2021
\end{abstract}

\begin{abstract}
The Covid-19 pandemic situation has demanded all aspects to adjust. Students are forced to make various adjustments, both learning patterns, demands for adapting new habits, and adherence to health protocols. However, the mental impact on students is unknown. This study aims to identify the impact of the Covid19 pandemic on the mental condition of students and the need for psychological support needed for students. This study uses a qualitative method with data collection techniques through online surveys with the target of student respondents coming from Jakarta and the selection of respondents is random and the analysis is carried out descriptively. This study found that the impact of the Covid-19 pandemic on the mental condition of students in Jakarta included; feelings of boredom, confusion, fear, anxiety, and stress. The support needed for students facing the Covid-19 pandemic is family support, friend support, and facility support to carry out positive activities.
\end{abstract}

Keywords: Covid-19 Pandemic, Mental Students, Psychological Support

\section{Abstrak}

\begin{abstract}
Situasi pandemi Covid-19 telah menuntut semua aspek untuk menyesuaikan. Peserta didik dituntut melakukan berbagai penyesuaian, baik pola belajar, tuntutan adaptasi kebiasaan baru serta kepatuban pada protokol kesehatan. Namun demikian, belum diketabui dampak secara mental terhadap peserta didik di Jakarta. Penelitian ini bertujuan untuk mengidentifikasi dampak pandemi covid-19 terhadap kondisi mental peserta didik dan kebutuban dukungan psikologis yang diperlukan bagi peserta didik. Penelitian ini menggunakan metode kualitatif dengan teknik pengumpulan data melalui survey secara online dengan sasaran responden peserta didik berasal dari Jakarta dan pemiliban responden secara random serta analisis dilakukan secara deskriptif. Penelitian ini menemukan bahwa dampak pandemi covid-19 terbadap kondisi mental peserta didik di Jakarta meliputi; perasaan bosan, bingung, ketakutan, cemas dan stress. Dukungan yang diperlukan bagi peserta didik. menghadapi pandemi covid-19 yaitu dukungan keluarga, dukungan teman dan dukungan fasilitas untuk melaksanakan kegiatan positif.
\end{abstract}

Kata kunci : Pandemi Covid-19, Mental Peserta Didik, Dukungan Psikologis

\section{Introduction}

The Corona virus has plagued the world since December 2019. Today, more than 3.6 million people in the world have died. The origin of this virus came from Wuhan, China ${ }^{1}$ then spread rapidly to various other countries including Indonesia around March 2020. The

${ }^{1}$ Heng Li and Et.all, "International Journal of Antimicrobial Agents," International Journal of Antimicrobial Agents 55 (2020): 1-5. impact of the spread of the virus is very complex for the Indonesian people because it has had a major impact on almost all aspects of life.

The government issued Presidential Decree No. 11 of 2020 concerning the Determination of the Corona Virus Disease 2019 Public Health Emergency, as a form of 
the state's commitment to providing protection for the citizens. The decision stipulates that the corona virus-19 is a type of disease that causes a public health emergency. Consequently, the government, regional governments together with all elements of society work together to take the best steps to provide health protection for citizens so that the number of exposed cases can be prevented. Considering the case of the spread of the virus-covid-19 which is increasingly widespread and becomes a serious threat to the community, the President has declared Corona Virus -19 as a national disaster. $^{2}$

The Covid-19 pandemic has made all elements of the nation try to break the chain of transmission quickly, change old patterns of life to new patterns, change old patterns of social interaction to new patterns, change old patterns of religious activities to new patterns, changing the pattern of old education services to a new pattern that is safe and has no impact on the spread of Covid-19. The demand for a shift in the old pattern of life to a new life pattern is not easy, because it requires awareness and commitment to answer needs, including in education services. In the context of education, innovative breakthroughs are part of efforts to adapt to the Covid-19 situation which requires policies, strategies, and innovations to produce new educational service models. ${ }^{3}$

The impact of Covid-19 is felt not only for early childhood education services but also for basic education, secondary education, and higher education. Demands for curriculum adjustments in the Covid-19 pandemic

2 Sugihantono Anung and Dkk, Pedoman Pencegahan Dan Pengendalian COVID-19, Math Didactic: Jurnal Pendidikan Matematika, vol. 4 (Jakarta: Kementerian Kesehatan, 2020).

3 Iswantir M Zulfani Sesmiarnia, "The Assessment of Online Learning in IAIN , Bukittinggi, During the Covid-19 Pandemic," International Journal of Innovation, Creativity and Change 13, no. 11 (2020): 1213.

4 Agusriandi Agusriadi et al., "Technical Guidance for Learning Management in a Video situation have also been voiced by various elements. In a disaster situation, it is certainly not appropriate to continue to use the curriculum in normal situations. Responding to input from various experts including the Indonesian Child Protection Commission (KPAI), the government finally responsively made curriculum adjustments in emergency situations. This is not only an education unit under the guidance of the Ministry of Education and Culture but also a madrasah education unit and other religious education units under the guidance of the Indonesian Ministry of Religion.

With the impact of Covid-19, teacher competencies are also required to adjust. Previously, the use of technology and information by educational units or educators had adequate readiness both system support, human resources, and supporting facilities in the use of technology-based learning media, but with the Covid-19 pandemic situation, all educational units and educators are required to adapt. ${ }^{4}$ Thus, educators who do not have the ability to use technology and information will slowly be replaced with competent educators, considering that the world has changed, and education services must adapt quickly.

In terms of regulation, adjustment of education services, a joint decision has been issued between the Minister of Education and Culture, Minister of Religion, Minister of Health, and Minister of Internal Affairs concerning Guidelines for the Implementation of Learning in the Covid-19 Pandemic Period. Furthermore, the decision is followed up

Conference with the Zoom and Youtube Application in the Covid-19 Pandemic Era," in Journal of Physics: Conference Series, vol. 1783 (IOP Publishing, 2021), 12119.

5 Barbara B Lockee, "Shifting Digital, Shifting Context:(Re) Considering Teacher Professional Development for Online and Blended Learning in the Covid-19 Era," Educational Technology Research and Development 69, no. 1 (2021): 17-20. 
through the policy of the Ministry of Education and Culture by issuing Circular Letter Number 15 of 2020 concerning Guidelines for the Implementation of Learning from Home in an Emergency Period for the Spread of Covid-196 and the Circular Letter of the Minister of Education and Culture Number 4 of 2020 concerning the Implementation of Education in the Coronavirus Disease (Covid-19) Emergency Period.

In principle, the content of the regulation emphasizes the importance of continuing education services, with various adjustments, namely adjustments to curriculum policies in emergency situations and learning services that guarantee the safety and security of students from the threat of Covid-19 transmission, adjustment of learning services from home with the support of tools. technology help. With this policy, educators are required to be able to adapt to the demands of technological progress and make innovative breakthroughs in learning services without being limited by space and time constraints ${ }^{7}$. The spirit of this policy is actually a form of protection for children, preventing the spread of Covid-19 from expanding so that the number of exposed cases can be suppressed as much as possible.

The change in the pattern of education services is actually the safest alternative to protect students from the threat of being exposed to Covid-19. Consequently, all school members must be willing to adapt to new policies, physical interactions change to virtual interactions, exemplary approaches, and

6 Kementerian Pendidikan dan Kebudayaan, "Kementerian Pendidikan dan Kebudayaan," Http:/ / Kemdikbud.Go.Id/, 2020.

7 Liza Efriyanti and Firdaus Annas, "Aplikasi Mobile Learning Sebagai Sarana Pembelajaran Abad 21 Pada Era Revolusi Industri 4.0," Jurnal Educative: Journal of Educational Studies, 2020.

${ }^{8}$ Febria Sri Artika, Widya Syafitri, and Risdaneva Risdaneva, "Developing Life Skill Based English Instructional Material in Bilingual Pesantren," Al-Ta lim Journal 27, no. 3 (2020): 272-281. character development change through virtual, school activities replaced with activities at home with the help of parental assistance. A professional teacher should recognize that the material plays a critical role in the whole curriculum, and that it must be adequately prepared in accordance with competency requirements and basic competencies. ${ }^{8}$

Although the policy of learning from home can significantly reduce the number of children exposed to Covid-19, to find out more about the impact of the Covid-19 situation on the mental condition of students, research is needed so that the impact is measurable and identified as a basis for finding the best learning service format. Moreover, students are separated from their friends for a long time, all learning and playing activities are carried out at home, teacher interaction is only done virtually, innovation in learning methods is virtually limited, the warmth of interaction is directly replaced and limited by virtual media and various other conditions as due to the covid-19 pandemic. ${ }^{9}$

Studies related to Covid -19 have been carried out by several researchers, but the focus of the research is different from what the researchers did. Studies on the relationship between covid-19 and the issue of learning services have been carried out by a number of other researchers including Wahyu Aji Fatma D. who studied the impact of Covid-19 toward the implementation of online learning in elementary school. ${ }^{10}$ The focus of this research explores the impact of Covid-19 in the

9 Siti Fatimah and Umi Mahmudah, "How ELearning Affects Students' Mental Health During Covid19 Pandemic: An Empirical Study," Dwija Cendekia: Jurnal Riset Pedagogik 4, no. 1 (2020): 114-124.

10 Wahyu Aji Fatma Dewi, "Dampak Covid-19 Terhadap Implementasi Pembelajaran Daring di Sekolah Dasar," Edukatif: Jurnal Ilmu Pendidikan 2, no. 1 (2020): 55-61. 
application of online learning in elementary schools, including the obstacles and constraints. Furthermore, research of Andina Amalia dan Nurus Sa'adaha also explores the impact of Covid-19 on changes in learning patterns in Indonesia, including the constraints and limitations of teachers' abilities. ${ }^{11}$ On the other hand, Rizqon Halal Syah Aji's research, entitled Dampak Covid-19 pada Pendidikan di Indonesia: Sekolah, Keterampilan, dan Proses Pembelajaran, focuses his research on the impact of Covid-19 on education services in Indonesia. $^{12}$

The novelty of this research lies in the effort to identify the impact of the Covid-19 pandemic, mentally for students in Jakarta and the need for the necessary support. The location selection was made based on considerations, first, all students in Jakarta conducted virtual-based learning from home for a long time; second, a number of cases of student complaints participating in learning from home have been reported to the Indonesian Child Protection Commission (KPAI) for various reasons of discomfort; third, some students due to the long-term policy of learning from home services require the assistance of service institutions to assist students.

The focus of this research is how is the impact of the Covid-19 pandemic on the mental condition of students in Jakarta, and what are the support needs for the comfort of students in Jakarta? Based on the focus of the problem, the purpose of the research in this article is to identify and describe the impact of the Covid -19 pandemic on the mental condition of students and the need for support needed for students in Jakarta.

11 Andina Amalia and Nurus Sa'adah, "Dampak Wabah Covid-19 terhadap Kegiatan Belajar Mengajar di Indonesia," Jurnal Psikologi 13, no. 2 (2021): 214-225.

\section{Research Methods}

In this study, the researcher used a qualitative method based on a virtual survey. The study was conducted on students from January to March 2021. The data sources for this research were junior high school and high school students with an age range of 13-17 years. The students who were used as respondents came from South Jakarta City, East Jakarta City, and West Jakarta City. In order to adjust to the Covid-19 situation, the data collection technique chosen by the researcher was the google form. Technically, the google form was delivered to student respondents spread across three cities that were randomly selected. Respondents amounted to 257 students. Descriptive analysis is used by researchers to describe the impact of the Covid -19 pandemic on the mental condition of students in Jakarta.

\section{Results and Discussion}

Based on the findings of research data related to the impact of the covid-19 pandemic on the mental condition of students in the Jakarta area, and the forms of support needed are summarized including; students' feelings in dealing with covid-19, students' attitudes towards the high number of cases, students' efforts when experiencing uncomfortable psychological conditions in dealing with covid19 , the variety of support needed for the comfort of students and forms of psychological support by families.

The results of the study found that the feelings of junior and senior high school students in Jakarta in facing the covid-19 pandemic were $40 \%$ bored, $22 \%$ confused, $23 \%$ scared, anxious $14 \%$ stressed, $1 \%$ normal.

12 Rizqon Halal Syah Aji, "Dampak Covid-19 pada Pendidikan di Indonesia: Sekolah, Keterampilan, dan Proses Pembelajaran," Salam: Jurnal Sosial dan Budaya Syar-i.(7) 5 (2020): 395-402. 
In detail, the feelings of junior and senior high school students in Jakarta in dealing with Covid -19 are shown in the following graph:

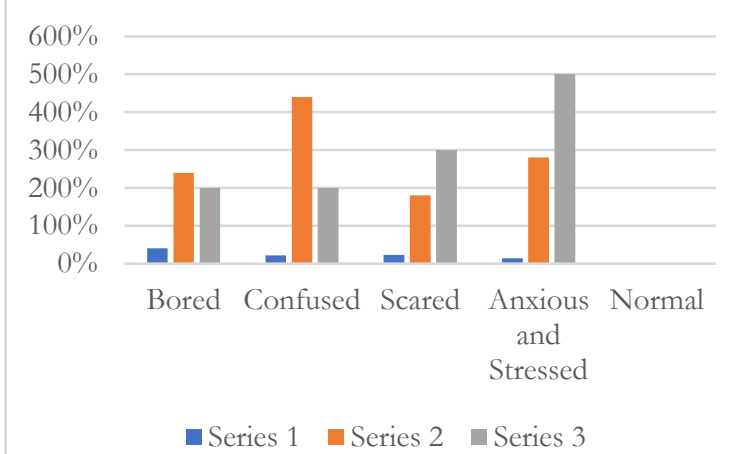

Figure 1. Students' Feelings Facing the Covid-19 Pandemic

\section{Students' Attitudes Against the High Case of Covid-19}

Based on the results of the study, it was found that students in Jakarta in dealing with the high number of Covid-19 cases in Indonesia, $51 \%$ of students were increasingly alert, $25 \%$ of students limited themselves, and $14 \%$ of students worried about being exposed to Covid-19. This attitude can be seen in detail in the graph below:

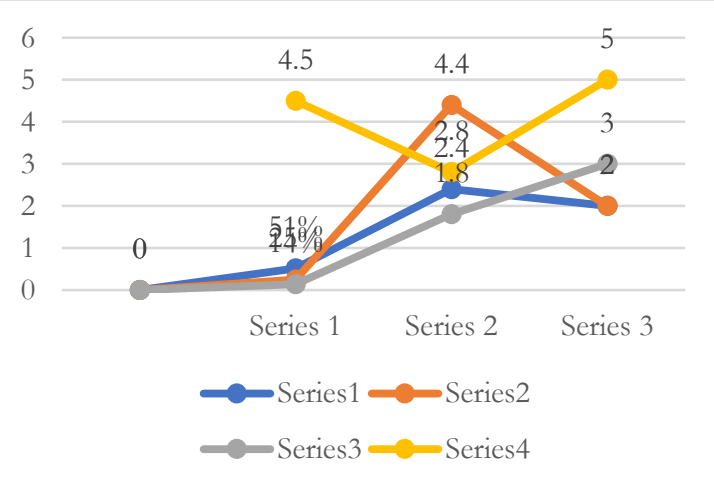

Figure 2. Students' Attitudes Against the High Case of Covid-19

\section{Activities Performed by Students When Psychological Conditions Feel Uncomfortable}

The results of the study found that when students were psychologically uncomfortable facing the Covid -19 pandemic, as many as 35\% of them admitted to telling stories with friends through social media, then $30 \%$ admitted to conveying their feelings to their parents, as many as $15 \%$ admitted to conveying it to teachers and $20 \%$ accessing services. In detail, the efforts of students can be seen in the graph below;

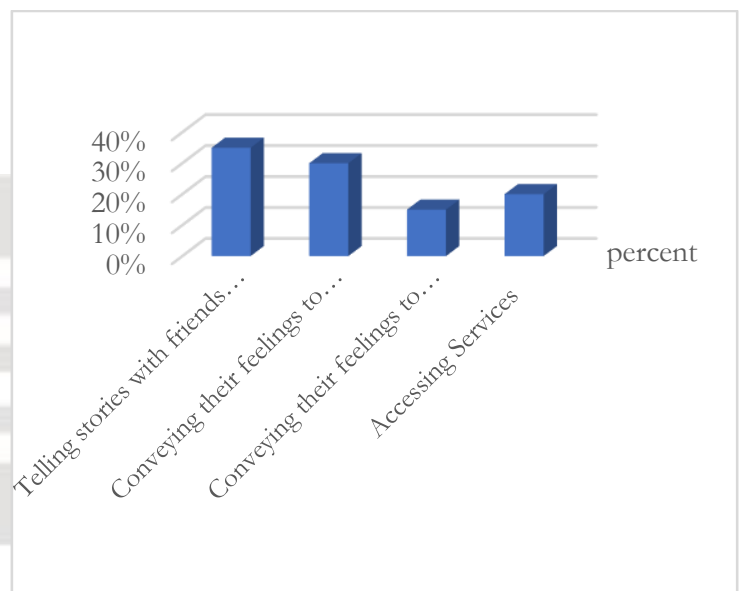

Figure 3. Efforts Made by Students When Psychological Conditions Are Uncomfortable

\section{The Necessary Support for The psychological Comfort of Students}

Based on the results of the study, it was found that students in Jakarta admitted that they needed support in various ways for their comfort, namely $45 \%$ of students claimed to need family support, $30 \%$ thought they needed the support of friends and $25 \%$ needed the support of adequate facilities to carry out positive activities. This can be seen in detail in the following graph:

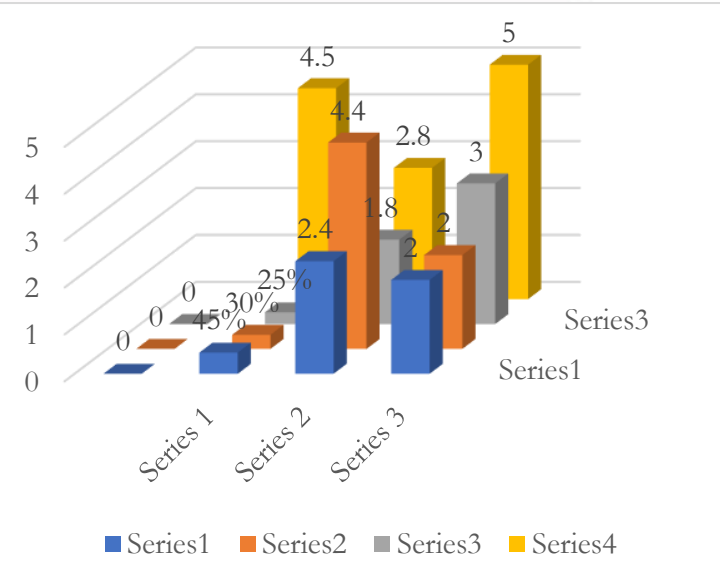

Figure 4. Support Needed for The Convenience of Students 


\section{The necessary form of Family Psychological Support}

The results of the study found that the form of family support needed for students to be comfortable in facing the covid-19 pandemic, namely, $25 \%$ of students claimed to need advice from their families, $35 \%$ claimed to need attention, 24\% claimed to need togetherness with family and 16\% needed motivation. In detail, the form of support referred to can be seen in the graph below:

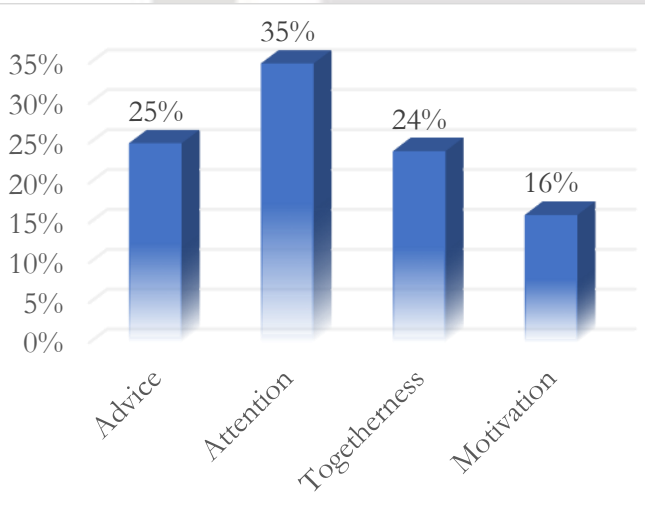

Figure 5. Forms of Psychological Support from Families for Students

\section{Discussion}

Based on the research findings, it shows that the Covid-19 pandemic situation has a negative impact on the mental condition of students. In fact, data shows that the mental situation of junior and senior high school students in Jakarta in dealing with the COVID19 pandemic is $40 \%$ bored, $22 \%$ confused, $23 \%$ scared, anxious $14 \%$ stressed, and $1 \%$ are just normal. As a response to the Covid-19 condition, in dealing with the high number of Covid-19 cases in Indonesia, 51\% of students are increasingly wary, $25 \%$ are self-limiting and $24 \%$ are worried about being exposed to Covid-19.

13 Pramawati Rita and Dkk, "Survey Nasional Pemenuhan dan Perlindungan Khusus Anak Tahun 2020" (Jakarta: KPAI, 2020).

14 Charalambos Papageorgiou Konstantinos Kontoangelos, Marina Economou, "Mental Health Effects of COVID-19 Pandemia: A Review of Clinical
The portrait of the mental condition confirmed from the results of the National Survey of the Indonesian Child Protection Commission (KPAI) in 2020, there are $63 \%$ of children aged $63 \%$ feeling bored because of various restrictions and demands for health protocols ${ }^{13}$. According to Konstantinos, et al., the emergence of feelings of worry, fear, and stress is a natural reaction to changes and uncertain situations experienced by everyone ${ }^{14}$ including students. This is due to the change from open social relations to closed social relations and is limited in the family including relationships in the learning process that requires learning from home. Another study reports that there is a negative impact of activities from home, even vulnerable to psychosomatic effects, namely a condition of physical disturbance as a result of a person's psychological or mental condition and emotional conditions that can cause shocks in the form of anxiety, pressure, boredom and social environmental situations that can affect negative thoughts of a person in his life ${ }^{15}$.

Mental conditions affected by the spread of Covid-19 do not only occur in Indonesia. Research involving 2,330 student respondents in Hubei, China, published in the JAMA Pediatrics Journal, reports that students who experience social restrictions in the process of studying at home to adjust the Covid-19 protocol policy, appear to pose a number of emotional problems vulnerabilities. The study reported that $22.6 \%$ of students who studied from home, from observations made seemed to

and Psychological Traits.," A Review of Clinical and Psychological Traits (USA, 2020).

${ }^{15}$ Diah Andika Sari et al., "Kesiapan Ibu Bermain Bersama Anak Selama Pandemi Covid-19, 'Dirumah Saja," Jurnal Obsesi : Jurnal Pendidikan Anak Usia Dini 5, no. 1 (July 2020): 475. 
experience signs of depression, while $18.9 \%$, tended to show signs of anxiety ${ }^{16}$.

Another study published Revista de Psicología Clínica con Niñosy Adolescent reports on the psychological impact of restrictive policies during the Covid-19 pandemic on schoolchildren living in the UK. A total of 927 reported changes in the child's emotional state and behavior during the restriction. The most frequently reported symptoms in children were boredom $(73.8 \%)$, followed by loneliness $(64.5 \%)$ and frustration (61.4\%). In addition, the behavior of irritability, restlessness, anger, anxiety, sadness, worry, and tendency to argue with other family members was reported by more than $30 \%$ of caregivers. During social distancing at home, school-age children spend more time using screens, and less time doing physical activity and sleeping. In addition, family coexistence during covid-19 is described as quite difficult. More than half of caregivers reported experiencing moderate or serious stress. These findings emphasize the importance of developing prevention programs to reduce the impact of the Covid-19 pandemic, especially related to psychological health for children and their families ${ }^{17}$.
This pandemic appears to have altered the psychology of students all around the world. Some of them have even considered suicide. ${ }^{18}$ 19202122 As a student, life is no longer easy for them. Their responsibilities as students have become too much for them. They are desperate because they live an abnormal existence that isolates them from their peers and prevents them from enjoying their adolescent.

According to Brazendale, et al., changes in learning patterns from school to home are vulnerable to impact the mentality of students. When students are not attending school, they are less physically active, spend more time on digital screens, have irregular sleep patterns and less favorable diets, and are more likely to gain weight ${ }^{23}$ and loss of cardiorespiratory fitness, which reflects the ability of the heart and lungs to efficiently circulate oxygenated blood to meet the body's metabolic needs. This negative effect tends to be exacerbated when social distancing measures are only carried out at home, with limited outdoor activities and no interaction with friends of the same age. In addition, understanding the elements that drive physical activity participation might inspire future policies and tactics targeted at delivering developmentally appropriate experiences,
16 Xinyan Xie et al., "Mental Health Status Among Children in Home Confinement During the Coronavirus Disease 2019 Outbreak in Hubei Province, China," JAMA Pediatrics 174, no. 9 (September 2020): 898.

17 Cecilia A. Essau Evren Morgül1, Angeliki Kallitsoglou2, "Psychological Effects of the Covid-19 Lockdown on Children and Families in the UK," Journal of Revista de Psicología Clínica con Niños y Adolescentes 7, no. 3 (2020): 42-48.

18 Michael L Tee et al., "Psychological Impact of COVID-19 Pandemic in the Philippines," Journal of affective disorders 277 (2020): 379-391.

19 Iqbal Pramukti et al., "Anxiety and Suicidal Thoughts during the COVID-19 Pandemic: CrossCountry Comparative Study among Indonesian, Taiwanese, and Thai University Students," Journal of medical Internet research 22, no. 12 (2020): e24487.
20 Aziz Essadek and Thomas Rabeyron, "Mental Health of French Students during the Covid-19 Pandemic," Journal of affective disorders 277 (2020): 392393.

21 Eman R Ghazawy et al., "Psychological Impacts of Covid-19 Pandemic on the University Students in Egypt," Health Promotion International (2020).

22 Rindi Ardika Melsalasa Saputri and Tri Yumarni, "Social Media Addiction and Mental Health Among University Students During the COVID-19 Pandemic in Indonesia," International Journal of Mental Health and Addiction (2021): 1-15.

23 P.T. Keith Brazendale, Beets, M.W.; Weaver, R.G.; Pate, R.R.; Turner-McGrievy, G.M.; Kaczynski, A.T.; Chandler, J.L.;Bohnert, A.; von Hippel, "International Journal of Behavioral Nutrition and Physical Activity," International Journal of Behavioral Nutrition and Physical Activity, 2017. 
ultimately enabling intrinsic motivation to seek out, and sustain, regular physical activity. ${ }^{24}$

Although the data confirms that students are mentally affected, not all efforts are made as expected. In fact, the results of research in Jakarta when students are in a psychologically uncomfortable condition, as many as $35 \%$ admit to telling stories with friends through social media, 30\% admit to conveying their feelings to their parents, as much as $15 \%$ claim to convey to the teacher and $20 \%$ of students access service. The positive thing from this finding is that quite a lot of students convey the conditions experienced to parents, teachers, and service institutions. However, there are still $35 \%$ of students telling their friends when they feel uncomfortable. Of course, students in this group need a change in behavior, so that if there are problems they can convey to their families, teachers, or service institutions, and not to their friends on social media.

This effect is reinforced by the opinion of Druss BG, that the Covid -19 pandemic is prone to causing concern and anxiety. Feelings of worry can worsen as well as be exacerbated by existing anxiety and depressive symptoms ${ }^{25}$ so that support from various parties is needed so that students are not mentally affected. Moreover, studies report that a healthy mental condition will affect the learning success of students. ${ }^{26}$

Therefore, the support of various elements is needed, especially the support of those closest to the child. Based on data findings, to be more comfortable dealing with Covid -19, as many as $45 \%$ of students claimed to need family support, $30 \%$ claimed to need the support of friends and $25 \%$ needed support for

24 Keith Brazendale, An Empirical Study of Children's Enjoyment and Perceived Competence in Physical Education and Its Effects on Their Physical Activity Participation Outside of School (Florida Atlantic University, 2013).

${ }^{25}$ Benjamin G. Druss, "Addressing the Covid-19 Pandemic in Populations With Serious Mental Illness," JAMA Psychiatry 77, no. 9 (September 2020): 891. adequate facilities to carry out positive activities. At the family level, psychological support is needed in dealing with the Covid -19 pandemic, namely, as many as $25 \%$ of students claim to need advice, $35 \%$ claim to need attention from family, $24 \%$ claim to need togetherness with family and $16 \%$ need motivation from family. This situation is in line with mental health guidelines published by the Covid-19 Task Force, which emphasizes that children in the age range $0-18$ years who are mentally affected, need the role of the family to ensure their mental health. The family is the main supporter in the recovery process in the form of informational, emotional support, taking time, and appreciation ${ }^{27}$.

The Covid-19 pandemic, which threatens the safety of human life, including school-age children, is a new problem that we must face proportionally. The existence of humans as creatures who have all the glory, resources, and inherent potential, should need to adapt to the challenges of the pandemic and the need for new protocols. Moreover, according to Musa Asy'ari, the human essence in etymological review is called human. The term human in Arabic comes from the word Nasiya which means "to forget". Furthermore, the basic word al-uns means "tame". The term human in verses and al-Hadith is used to refer to humans because humans have a tendency to forget and be docile. Tame in this context means that humans are always "trying to adapt" to a new or unfamiliar environment ${ }^{28}$. Thus, human nature is an adjustment to all situations encountered. Although by nature humans are social creatures that require interaction with

26 Evren Morgül1, Angeliki Kallitsoglou2, "Psychological Effects of the Covid-19 Lockdown on Children and Families in the UK."

${ }^{27}$ Tim Ahli, "Panduan Kesehatan Jiwa Pada Masa Pandemi Covid-19: Peran Keluarga Sebagai Pendukung Utama" (Jakarta: Satgas Covid-19, 2020).

28 Musa Asy'arie, "Filsafat Islam: Sunah Nabi dalam Berpikir” (Yogyakarta: LESFI, 2002). 
other people ${ }^{29}$, however, in the Covid -19 pandemic situation, restrictions are required as part of the new protocol in health. Consequently, every human being, including students, must have the readiness and ability to adapt to the new protocol, in order to remain physically and mentally healthy.

Conceptually, health is a state of being healthy and well, both physically healthy, mentally healthy, and spiritually and socially healthy. All aspects of health are equally important and mutually reinforcing each other. Someone who is physically healthy still needs to be mentally healthy and so on. Likewise, in order to maintain mental health, physical health must continue to be pursued. Mental health is a condition of a person who avoids complaints and mental disorders, both in the form of neurosis and psychosis. Mentally healthy will not be easily disturbed by pressure or stressors. Someone who has a healthy mentality will be able to manage emotions, regulate themselves, refrain from various pressures, both internal and external ${ }^{30}$. Mentally healthy, is the need of everyone, including students. Mental health is characterized by a state of psychological wellbeing. Someone who is mentally healthy will be able to shape and develop themselves into productive and effective individuals. Conversely, someone who is not mentally healthy will have an impact on his life and is prone to failure in life

Factors that affect mental health are family, school, and environmental factors. Family support plays an important role in forming a mentally healthy individual. If the family experiences disharmony, it has the potential to cause mental disabilities for family members, especially school-age children.

29 I Made Sonny Gunawan Akhmad Fajar Prasetya, "Mengelola Emosi" (Yogyakarta: K-Media, 2018).

30 Abdul Hamid, "Agama dan Kesehatan Mental dalam Perspektif Psikologi Agama," Jurnal Kesehatan Tadulako 3, no. 1 (2017): 1-8.
Furthermore, the condition of individuals who are mentally affected tends to be vulnerable to influencing learning activities. The impact of the emergence of psychological stress symptoms experienced by students also contributes to the emergence of various behavioral deviations, psychological stress, depression, anxiety, and trauma ${ }^{31}$.

Social restriction policies that have an impact on the adjustment of education services are still causing polemics. Some parents can understand the policy, but others feel that the policy is not appropriate, especially since many centers of economic activity remain open even though they have to comply with health protocols. The drastic change from learning at school to learning activities at home for students is not an easy matter, because it requires new adaptations and mental adjustments. For some students, learning and playing activities are only at school, not at home. The shifting of learning and playing time at school to a home environment using virtual support, for some children, is an unthinkable experience and even feels unfriendly to the condition of students. Some students have not been able to accept, even uncomfortable adapting to the demands of new adaptations and health protocol policies in the Covid-19 situation. Restrictions on activities outside the home for a long time are indeed vulnerable to impacting the mental condition of students. To prevent this, a synergistic partnership is needed from all elements of education stakeholders including parents and the social environment of students.

Mental or emotional factors will determine the success of students in learning during the pandemic. The study from home policy, which

31 Ifdil, "Mengembangkan Kesehatan Mental di Lingkungan Keluarga dan Sekolah," Journal of Innovative Counseling 2, no. 2 (2018): 1-9. 
has been an alternative learning service during the Covid -19 pandemic, seems to cause negative emotions for students, such as; boredom, worry, or another negative, which become a serious challenge for teachers in educational services, so that new breakthroughs are needed as alternatives so that the quality of learning can be well maintained.

Positive emotions can generate new enthusiasm, optimism, and productivity for students in learning. On the other hand, negative emotions can hinder the absorption and learning process of students and can even have a serious impact, including the failure of students to learn and achieve their goals. In fact, a number of countries carry out various evaluations of their education systems by accommodating emotional intelligence integrated in the national curriculum, including the United States. For example; The Social Emotional Learning (SEL) program in the USA, is an effort to strengthen character as well as to reduce behavioral deviations in students.

Because of the importance of emotional intelligence, it is natural that a number of experts view that the contribution of intellectual intelligence to one's success is only $20 \%$ while emotional intelligence reaches $80 \%$. Thus, efforts to stimulate students to have the ability to self-regulate, self-control, communicate, collaborate, empathize and be sensitive to their environment are part of mental intelligence, which must be grown programmatically, directed and sustainable, including in the Covid -19 situation.

Based on the description above, psychological support from various elements for students is very necessary so that the perceived vulnerabilities due to the Covid -19 pandemic can be prevented and handled properly and do not have a complex impact on the lives of students. For students who have a better level of emotional intelligence, will have resilience, are more skilled at adapting, focus and love on positive activities, always enthusiastic, optimistic, persistent in realizing ideals for a better future.

\section{Conclusion}

Based on the description and discussion, it can be concluded that the impact of the COVID-19 pandemic on the mental condition of students in Jakarta includes; bored, confused, scared, anxious and stressed. In response to the high number of cases of Covid19 conditions, some students are increasingly vigilant, limiting themselves and there are students who are worried about being exposed to Covid -19. The support they need in dealing with the Covid -19 pandemic, mainly comes from family support, friend support and facility support to carry out positive activities. At the family level, the psychological support needed is advice, attention from the family and togetherness and motivation from the family.

The results of this study are important as input and consideration for educational units to ensure all students are able to adapt to changes and new demands for health protocols and can be a consideration for teachers and parents to always provide psychological support to students.

\section{References}

\section{Book}

Asy'arie, Musa. "Filsafat Islam: Sunah Nabi Dalam Berpikir." Yogyakarta: LESFI, 2002.

\section{Journal}

Agusriadi, Agusriandi, Elihami Elihami, Mutmainnah Mutmainnah, and Yunus Busa. "Technical Guidance for Learning Management in a Video Conference with the Zoom and Youtube Application in the Covid-19 Pandemic Era." In Journal of Physics: Conference Series, 1783:12119. IOP Publishing, 2021.

Aji, Rizqon Halal Syah. "Dampak Covid-19 Pada Pendidikan di Indonesia: Sekolah, Keterampilan, dan Proses Pembelajaran." 
Salam: Jurnal Sosial dan Budaya Syar-i.(7) 5 (2020): 395-402.

Akhmad Fajar Prasetya, I Made Sonny Gunawan. "Mengelola Emosi." Yogyakarta: K-Media, 2018.

Amalia, Andina, and Nurus Sa'adah. "Dampak Wabah Covid-19 terhadap Kegiatan Belajar Mengajar di Indonesia." Jurnal Psikologi 13, no. 2 (2021): 214-225.

Anung, Sugihantono, and other. Pedoman Pencegahan dan Pengendalian Covid-19. Math Didactic: Jurnal Pendidikan Matematika. Vol. 4. Jakarta: Kementerian Kesehatan, 2020.

Artika, Febria Sri, Widya Syafitri, and Risdaneva Risdaneva. "Developing Life Skill Based English Instructional Material in Bilingual Pesantren." Al-Ta lim Journal 27, no. 3 (2020): 272-281.

Brazendale, Keith. An Empirical Study of Children's Enjoyment and Perceived Competence in Physical Education and Its Effects on Their Physical Activity Participation Outside of School. Florida Atlantic University, 2013.

Dewi, Wahyu Aji Fatma. "Dampak Covid-19 terhadap Implementasi Pembelajaran Daring di Sekolah Dasar." Edukatif: Jurnal Ilmu Pendidikan 2, no. 1 (2020): 55-61.

Druss, Benjamin G. "Addressing the Covid-19 Pandemic in Populations With Serious Mental Illness." J $A M A$ Psychiatry 77, no. 9 (September 2020): 891.

Efriyanti, Liza, and Firdaus Annas. "Aplikasi Mobile Learning sebagai Sarana Pembelajaran Abad 21 pada Era Revolusi Industri 4.0." Jurnal Educative: Journal of Educational Studies, 2020.

Essadek, Aziz, and Thomas Rabeyron. "Mental Health of French Students during the Covid-19 Pandemic." Journal of affective disorders 277 (2020): 392-393.

Evren Morgül1, Angeliki Kallitsoglou2, Cecilia A. Essau. "Psychological Effects of the Covid-19 Lockdown on Children and Families in the UK." Journal of Revista de Psicología Clínica con Niños y Adolescentes 7, no. 3 (2020): 42-48.

Fatimah, Siti, and Umi Mahmudah. "How ELearning Affects Students' Mental Health During Covid-19 Pandemic: An Empirical Study." Dwija Cendekia: Jurnal Riset Pedagogik 4, no. 1 (2020): 114-124.
Ghazawy, Eman R, Ashraf A Ewis, Eman M Mahfouz, Doaa M Khalil, Ahmed Arafa, Zeinab Mohammed, El-Nabgha F Mohammed, Ebtesam E Hassan, Sarah Abdel Hamid, and Somaya A Ewis. "Psychological Impacts of Covid-19 Pandemic on the University Students in Egypt." Health Promotion International (2020).

Hamid, Abdul. "Agama dan Kesehatan Mental dalam Perspektif Psikologi Agama." Jurnal Kesehatan Tadulako 3, no. 1 (2017): 1-8.

Ifdil. "Mengembangkan Kesehatan Mental di Lingkungan Keluarga dan Sekolah." Journal of Innovative Counseling 2, no. 2 (2018): 1-9.

Keith Brazendale, Beets, M.W.; Weaver, R.G.; Pate, R.R.; Turner-McGrievy, G.M.; Kaczynski, A.T.; Chandler, J.L.;Bohnert, A.; von Hippel, P.T. "International Journal of Behavioral Nutrition and Physical Activity." International Journal of Behavioral Nutrition and Physical Activity, 2017.

Konstantinos Kontoangelos, Marina Economou, Charalambos Papageorgiou. "Mental Health Effects of Covid-19 Pandemia: A Review of Clinical and Psychological Traits." A Review of Clinical and Psychological Traits. USA, 2020.

$\mathrm{Li}, \mathrm{Heng}$, and Et.all. "International Journal of Antimicrobial Agents." International Journal of Antimicrobial Agents 55 (2020): 1-5.

Lockee, Barbara B. "Shifting Digital, Shifting Context:(Re) Considering Teacher Professional Development for Online and Blended Learning in the Covid-19 Era." Educational Technology Research and Development 69, no. 1 (2021): 17-20.

Pramukti, Iqbal, Carol Strong, Yajai Sitthimongkol, Agus Setiawan, Moses Glorino Rumambo Pandin, Cheng-Fang Yen, Chung-Ying Lin, Mark D Griffiths, and Nai-Ying Ko. "Anxiety and Suicidal Thoughts during the Covid-19 Pandemic: Cross-Country Comparative Study among Indonesian, Taiwanese, and Thai University Students." Journal of medical Internet research 22, no. 12 (2020): e24487.

Rita, Pramawati, and Dkk. "Survey Nasional Pemenuhan Dan Perlindungan Khusus 
Anak Tahun 2020.” Jakarta: KPAI, 2020. Saputri, Rindi Ardika Melsalasa, and Tri Yumarni. "Social Media Addiction and Mental Health Among University Students During the Covid-19 Pandemic in Indonesia." International Journal of Mental Health and Addiction (2021): 1-15.

Sari, Diah Andika, Rahmita Nurul Mutmainah, Ika Yulianingsih, Tiara Astari Tarihoran, and Munifah Bahfen. "Kesiapan Ibu Bermain Bersama Anak Selama Pandemi Covid-19, 'Dirumah Saja."' Jurnal Obsesi: Jurnal Pendidikan Anak Usia Dini 5, no. 1 (July 2020): 475.

Tee, Michael L, Cherica A Tee, Joseph P Anlacan, Katrina Joy G Aligam, Patrick Wincy C Reyes, Vipat Kuruchittham, and Roger C Ho. "Psychological Impact of COVID-19 Pandemic in the Philippines." Journal of affective disorders 277 (2020): 379_ 391.

Tim Ahli. "Panduan Kesehatan Jiwa Pada Masa Pandemi Covid-19: Peran Keluarga
Sebagai Pendukung Utama." Jakarta: Satgas Covid-19, 2020.

Xie, Xinyan, Qi Xue, Yu Zhou, Kaiheng Zhu, Qi Liu, Jiajia Zhang, and Ranran Song. "Mental Health Status Among Children in Home Confinement During the Coronavirus Disease 2019 Outbreak in Hubei Province, China." JAMA Pediatrics 174, no. 9 (September 2020): 898.

Zulfani Sesmiarnia, Iswantir M. "The Assessment of Online Learning in IAIN, Bukittinggi , During the Covid-19 Pandemic." International Journal of Innovation, Creativity and Change 13, no. 11 (2020): 1213.

\section{Online Reference}

Kementerian Pendidikan dan Kebudayaan. "Kementerian Pendidikan Dan Kebudayaan." Http://Kemdikbud.Go.Id/, 2020 